ARTICLE

\title{
Work-life balance in Higher Education: a systematic review of the impact on the well-being of teachers
}

\author{
Luciane Silva Franco a \\ Claudia Tania Picinin ${ }^{b}$ \\ Luiz Alberto Pilatti ${ }^{c}$ \\ Antonio Carlos Franco ${ }^{d}$
}

\section{Abstract}

The work-life balance needs to be exercised by individuals who perform functions in the fields of work and family, including Higher Education teachers. The purpose of this paper is to analyze the work-life balance in Higher Education and the impact on the well-being of teachers. Based on a systematic review of 53 articles retrieved from the ScienceDirect, Scopus and Web of Science from 2005 to 2020, this article has a rigorous systematic review methodology using the Mendeley and EndNote software tools. The VOSviewer and Microsoft Excel software tools were also used in the following techniques: citation analysis and co-ocurrence of terms/words. In addition, main topics discussed about the work-life balance among Higher Education teachers, research areas, field of activity and SWOT analysis (opportunities, threats, strengths and weaknesses) were identified in the literature. Findings suggest that gender inequality, stress level at work and the absence of a healthy workplace impact on the work-life balance and consequently on the well-being of Higher Education teachers.

Keywords: Work-life balance. Teacher. University. Higher Education.

\footnotetext{
a Universidade Tecnológica Federal do Paraná, Ponta Grossa, PR, Brasil.

b Universidade Tecnológica Federal do Paraná, Ponta Grossa, PR, Brasil.

c Universidade Tecnológica Federal do Paraná, Ponta Grossa, PR, Brasil.

d Universidade Tecnológica Federal do Paraná, Ponta Grossa, PR, Brasil.
} 


\section{Introduction}

Work-life balance refers to achieving a balance between professional and personal life through the management, organization and prioritization of personal tasks and work routines (FAZAL et al., 2019). Several researches suggest that academic administration develop strategies for maintaining and developing the work-life balance of teachers in their academic careers (AMITH; VINAY; GOWRAMMA, 2019; SONI; BAKHRU, 2019).

Considered as the fundamental asset in Higher Education institutions (HEIs), the teacher plays a representative role in the execution of organizational objectives and their performance influences the learning process and student results (GOODING, 2018; SETHI et al., 2017), directly intervening in the goals of any Education program (JOHNSON; WILLIS; EVANS, 2019). Research has identified that teachers presented the most unstable work-life balance when compared to other positions in Higher Education institutions (BEER et al., 2015; KANG; PARK; PARK, 2019). Studies that analyzed the teachers' work-life balance have limitations in terms of explaining the specific aspects that contribute to this instability (EBERMAN; SINGE; EASON, 2019; KRUEGER et al., 2017; NILSSON; BLOMQVIST; ANDERSSON, 2017). The understanding of work-life balance indicators is representative in this research audience, since the well-being of teachers can influence their productive effectiveness in teaching, research and management, ultimately interfering in the quality of Higher Education (ABRAMOV; GRUZDEV; TERENTEV, 2017).

The absence of favoring the work-life balance in the face of teachers who work in the university environment can affect their commitment both in the area of teaching and in research, and can also generate distance from family commitments. The work-life balance of teachers can be an attenuator not only for the quality of Education, but also to make undergraduate and graduate programs more sustainable, with impacts in the short and long time (BEER et al., 2015; DEVI; LALU, 2018; ZEHRA; RUKHSANA, 2020). Therefore, it is something that demands from teachers, during the career formation period, to receive an adequate structure so that the work environment can remain healthy. Higher Education teachers face continuous tension regarding the quality of classes, publication of scientific research, excessive workload, deadlines, constant performance evaluations by programs, requirements for frequent participation in academic events, among other activities inherent to the profession (BEIGI; SHIRMOHAMMADI; KIM, 2016; DUBAS-JAKOBCZYK et al., 2020; JOHNSON; WILLIS; EVANS, 2019). 
Insecurity in living with the coordinators is aggravating stress (BERHEIDE et al., 2020; PU et al., 2017), as well as the various activities that university teachers carry out, in their personal lives as parents and in career building also as students, and in professional life as researchers and employees (MCCUTCHEON; MORRISON, 2018). Regarding the number of factors that generate aggravating stress and the job responsibilities of teachers, maintaining the balance between professional and family life becomes another challenge (FAZAL et al., 2019). Due to the conflicts generated between professional and family environment, some teachers in career construction give up academic life soon after finishing the doctoral course, exercising other professions (CABAY et al., 2018). However, there are data that show that Higher Education institutions do not favor the career building of teaching professionals. Instead, the work environment at universities is seen as expensive by several teachers, which influences the work-life balance in a harmful way (JAIN; MISHRA; YADAV, 2018).

Research on the work-life balance of Higher Education teachers and other professionals working at universities has deepened in factors such as stress level (DEVI; LALU, 2018), workload (SALTMARSH; RANDELL-MOON, 2015) and production scientific (YOU, 2016) in isolation, instead of using a global approach, as it would allow to consider several related aspects in the development of the work-life balance (KRUEGER et al., 2017; SMELTZER et al., 2016). Therefore, after researching the literature, this article aims to analyze the work-life balance and the impact on the well-being of Higher Education teachers, through a systematic review of the existing literature, answering the following questions: (i) What are the main impacts of work-life balance on the well-being of Higher Education teachers? (ii) What are the main strengths, weaknesses, opportunities and threats for the development of the work-life balance of Higher Education teachers?

The research is structured as follows. This first section presents the introduction and the objectives proposed in the study. The next section presents the methods used to carry out the research. Following are the main results found and, in closing, the conclusion of the study.

\section{Methodology}

This study has retrieved data from the ScienceDirect, Scopus and Web of Science, a comprehensive database that has been used extensively by various researchers for carrying out systematic reviews (NORRIS; OPPENHEIM, 2007; SEDIGHI, 2016). The choice of databases is justified by being the largest bases of bibliographic references and abstracts of the scientific literature of peer review. This provides a multidisciplinary scientific analysis with the integration 
of innovation, technology and applied research (ARCHAMBAULT et al., 2009). According to Norris and Oppenheim (2007), ScienceDirect, Scopus and Web of Science feature coverage of high-impact articles and extensive bibliographic coverage in the area of Social Sciences.

Figure 1- Summary of literature review steps

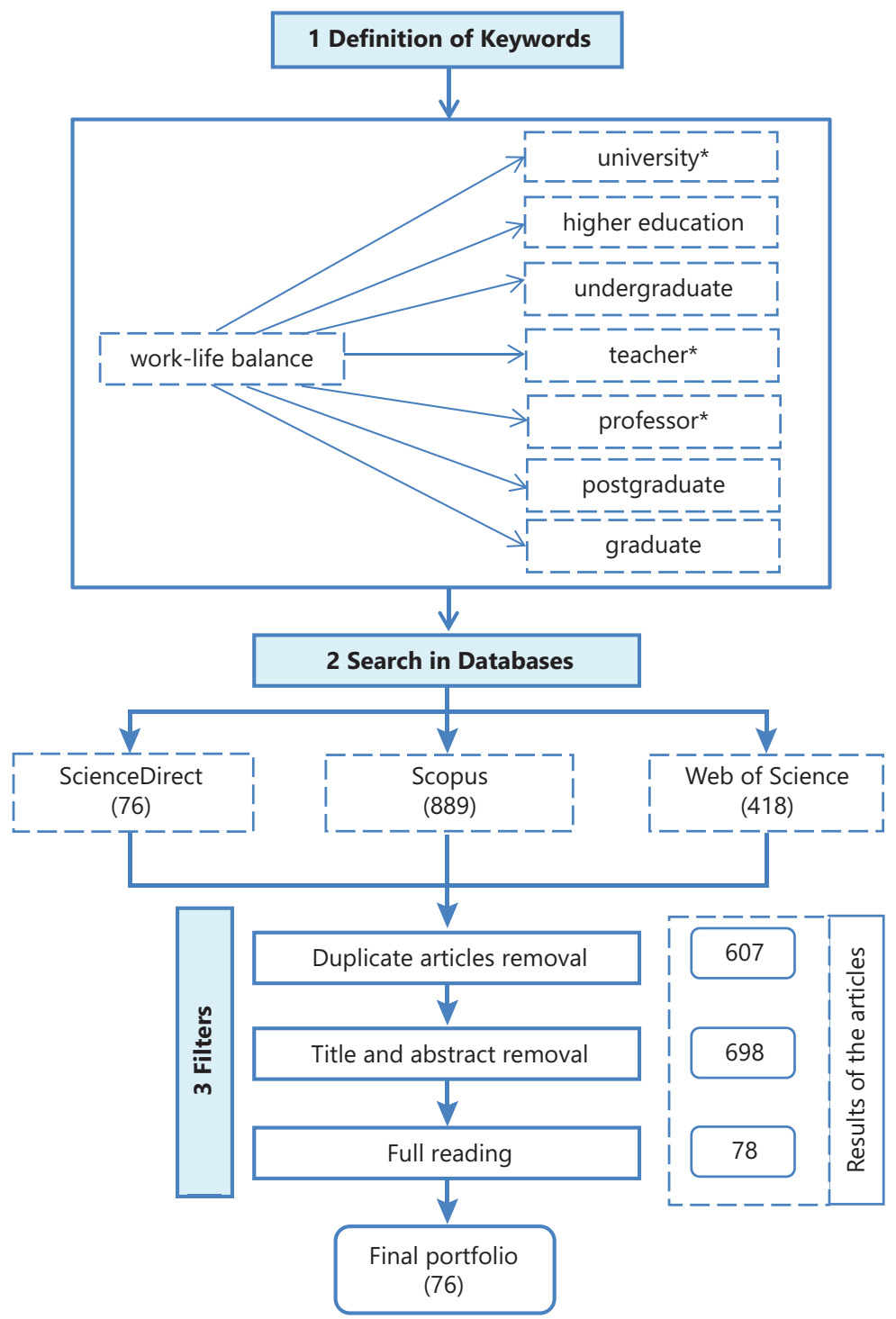

Source: Own Authorship (2020) 
The set of keywords used in the search was defined using Boolean operators and truncation symbols (see Figure 1). After searching the databases, 1383 articles were found. The authors did no limit time coverage. Thereafter, to select articles of relevance for the study, filtering procedures were adopted. The following criteria were used: (a) exclusion of duplicates using Mendeley (version 1.17.13) and EndNote X6; (b) restriction for inclusion of articles and review, eliminating books, book chapters and conferences; and (c) articles not related to the proposed theme were deleted - filter by title and summary, followed by full reading.

In total, 607 duplicate articles were eliminated; thus, of the 1,383 remained 776. After the title filter, since there were studies that did not fit in this research, there were 477 left. The filter by abstract was also applied and after reading the abstracts, 246 articles that did not fit the theme were identified and eliminated, and therefore, a total of 723 articles were eliminated by titles and abstracts. At last, after full reading of the articles, 53 articles have been selected for the final portfolio in a rigorous methodology of systematic review.

The final portfolio of the 53 articles is analyzed in the results section, in which the articles were organized by bibliometric analysis and the VOSViewer ${ }^{\circledR}$ software was used to construct visual maps (VAN ECK; WALTMAN, 2009). Bibliometric analysis manifests interconnections among the articles in respect of the frequency with which an article is cited and co-cited by other articles (BESSELAA; HEIMERIKS, 2006). The following techniques of bibliometric analysis have been adopted for this study: citation analysis, and co-occurrence of terms/words. The SWOT analysis was carried out to address the proposed research questions of this study (Strengths, Weaknesses, Opportunities, and Threats - the initials SWOT). The business strategy tool was invented by a group of Harvard teachers: Learned, Christensen, Andrews and Guth - in order to identify strategic options for a business or project (LEARNED et al., 1965). The citation analysis discusses the countries, institutions, journals and articles that have been scientifically influential according to the number of citations (DZIKOWSKI, 2018). In addition, main topics discussed about the work-life balance, research areas, field of activity (Teaching, research and management) are presented in the literature.

The co-occurrence of terms/words identified the main trends in the field that need to be investigated (SEDIGHI, 2016). In the SWOT analysis, strengths, weaknesses, opportunities and threats were identified. The significance of SWOT analysis is that it provides a good way to examine both positive and negative attributes within a single analysis, determining how best to build solutions for the problem in analysis (HELMS; NIXON, 2010). 


\section{Results of the characteristics found in the studies}

\subsection{Citation analysis}

This section considers a total of 53 articles written by 152 authors and co-authors published in 39 journals, from 2005 to May 2020, developed by 18 countries in 46 Teaching and research institutions, with a total number of 455 keywords and 2,286 references cited.

With regard to the number of publications, Figure 2 shows the number of articles per country.

Figure 2 - Number of publications per country

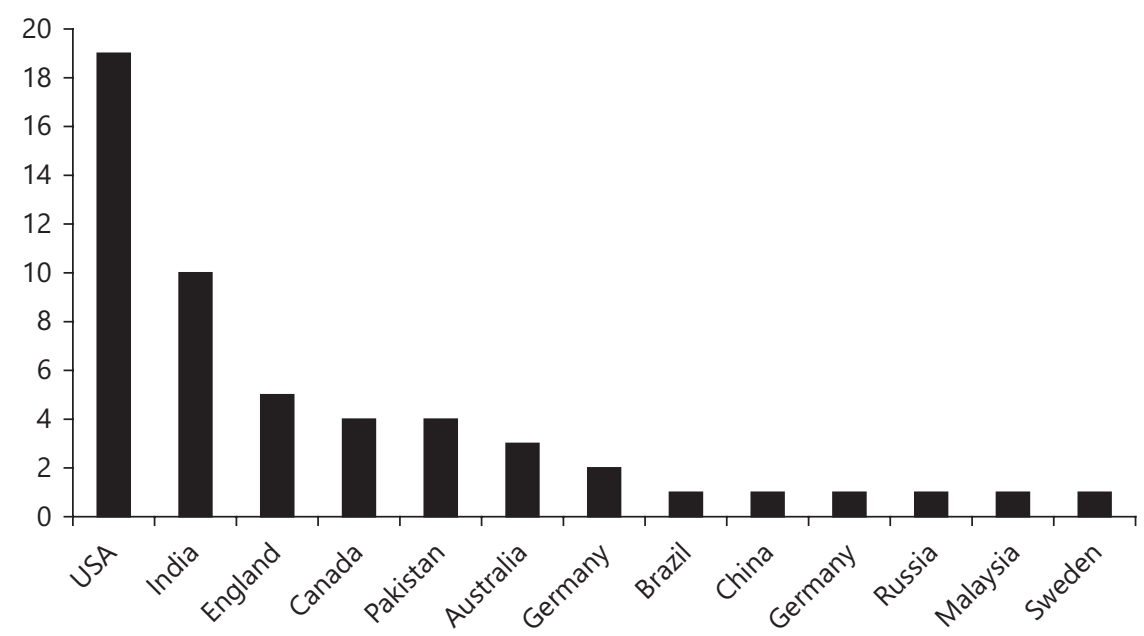

Source: Own Authorship (2020)

America is the continent with the largest number of publications related to the topic, since 24 of the 53 articles evaluated are from American countries. Asia also appears with a representative contribution of 16 publications. Among the countries with the highest number of searches are the USA (19 articles) and India (10 articles). The continents of Europe and Oceania are those that appear less prominently in relation to the topic addressed, with 10 and 3 articles respectively.

In the United States of America, research was carried out to contribute with new perspectives on the representation of women in HEIs, which revealed some 
barriers that included gender discrimination, lack of support from the faculty in the workplace, opposition from family members, need to choose between family and professional obligations (BEDDOES; PAWLEY, 2014; FAZAL et al., 2019). According to Lester (2015), Higher Education institutions need to deal with the individual nature of women's work-life balance considering the scenario of gender inequality. Similarly, India also appears prominently in research on the issue of gender (MARAGATHAM; AMUDHA; MOTHA, 2017; SUMATHI; VELMURUGAN, 2018). It was found that career development opportunities are one of the aspects that women most seek to work in the institution. For this reason, women's retention can be a vital source of competitive advantage in achieving the organization's goals and objectives, and the scenario is no different in Higher Education institutions (DHANYA; KINSLIN, 2017).

Regarding the institutions, few appear to be involved in more than one study. Only the University of California (3 studies), Faculty of Engineering at Trivandrum (2 studies) and Faculty of Nursing at the University of Villanova (2 studies). The reduced number of articles per institution allows us to infer that there is no study center that focuses on the proposed theme. Regarding the journals, the ones that published the most were International Journal of Stress Management and Journal of Athletic Training, both with 3 studies. It can be seen that the journals that publish the most on the topic work-life balance of Higher Education teachers are focused on the areas of psychology, administration and physical Education. These journals present studies on work-life balance with objectives aimed at the internal aspects of the institution, with an evaluation of the factors that develop a healthy work environment, such as support from co-workers, increased degree of retention of teachers and opportunities for career improvement.

Complementing the analysis, "Appendix A" shows the characteristics of the studies evaluated, presenting the authors, main topics discussed about work-life balance, study areas and practice field (Teaching, research and management). The articles were classified as most influential scientifically according to the number of citations.

Among the 53 articles, three articles with the highest number of citations were: Houston, Meyer and Paewai (2006), who mention that coordinators and teachers should take responsibility for defining their work functions, to build an active role in workload management; Tytherleigh et al. (2005), who state that the stress of Higher Education teachers is related to job insecurity; and the research carried out by Grawitch, Trares and Kohler (2007), provides initial support to the proposition that teachers' work-life balance should be integrated into the plans 
of Higher Education institutions, to ensure that the work-life imbalance does not affect the well-being of teachers and the quality of Teaching.

The body of literature demonstrates a diversity of research on the theme of work-life balance of teachers in Higher Education institutions. It appears that most journals belong to areas focused on Education (34.0\%), Medicine (30.2\%), Administration (28.3\%) and Psychology (26.4\%), emphasizing that some journals are related in more than one research area. Among the main topics discussed by the authors, gender inequality appears in $24.5 \%$ of the studies, followed by the level of stress at work with $22.6 \%$ and the absence of a healthy workplace with $15.1 \%$, with some articles classified in more than one topic. Figure 3 shows the list of studies evaluated according to the field of activity.

Figure 3 - Number of publications by field of activity

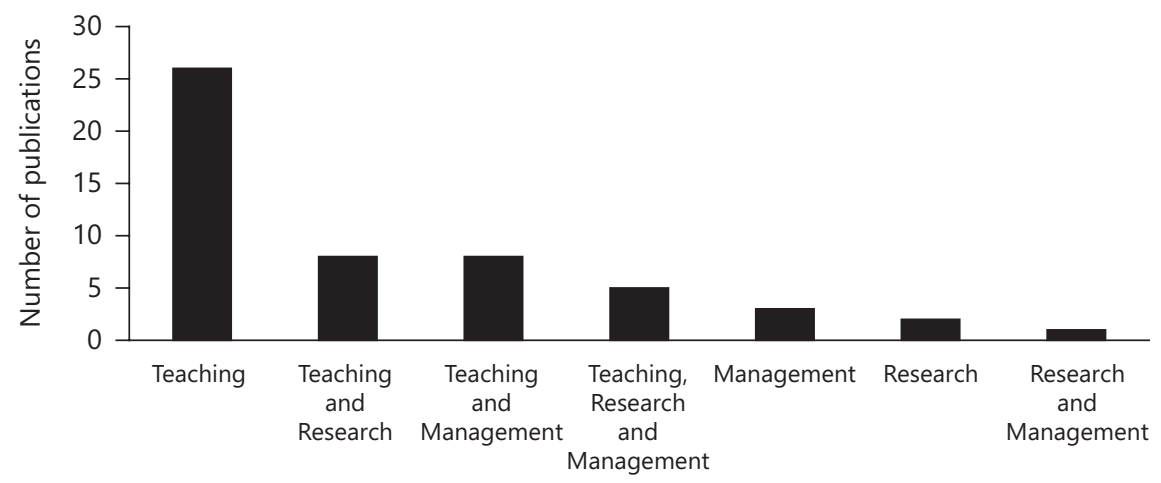

Source: Own Authorship (2020)

Most studies, $58.5 \%$ focused on the work-life balance of teachers in an isolated work field, with emphasis on Teaching. Among the 53 articles in the final portfolio, $41.5 \%$ showed a relationship in more than one field of activity, with Teaching and research as the main emphasis with $17.0 \%$ of the studies evaluated. Only $5.7 \%$ of the studies within the theme addressed evidenced the Teaching professionals who work specifically in management. This fact is worrying, since professionals who work in the positions of directors and deans are important for decision-making in Higher Education institutions; they are responsible for establishing policies in the workplace to meet the needs of employees to balance professional and personal responsibilities. However, the fact that there is little research that addresses management can be explained by the small number of teachers who work in university management. 


\subsection{Co-occurrence analysis}

A visual map was created with text data, in which titles and abstracts were considered (see Figure 4), the complete counting method was used, with a minimum number of occurrences of 10 keywords, thus 65 terms of a total of 2,291 meet the proposed criterion. Four clusters were identified with 604 elements of link occurrence.

Figure 4 - Co-occurrence of terms-final portfolio

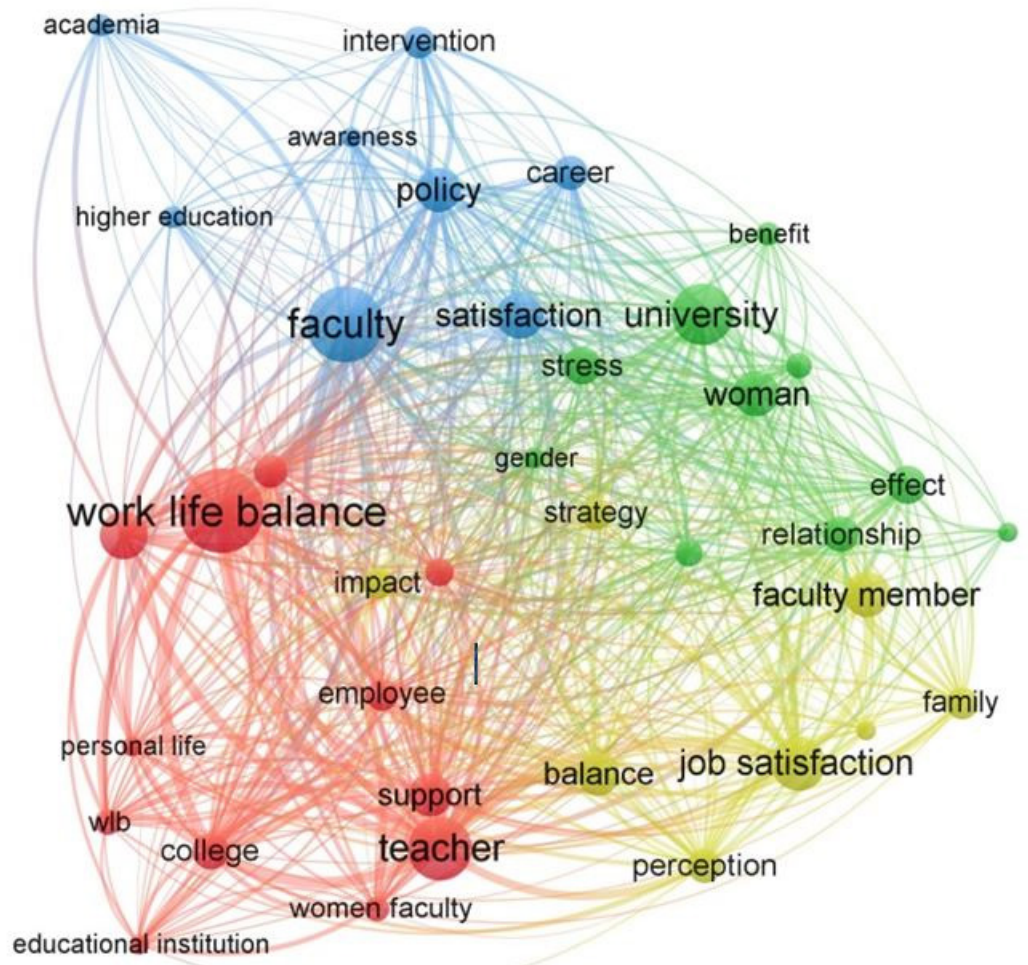

Source: Own Authorship (2020)

Therefore, from the existing results, it is possible to conclude that terms in red of the largest cluster mainly focus on studies that investigate work-life balance in Higher Education institutions, evaluating forms of support to balance the practices exercised by the members of the faculty in the workplace and in personal life. 
The second largest cluster with terms in green demonstrates studies regarding the work-life balance and the effect of the stress of the faculty members, highlighting the teachers' commitment to the university and how this can generate conflicts between work and family. In addition, the green cluster studies portray the issue of gender to assess whether the personal life of women has a greater impact on Teaching activities when compared to men. The main concerns within the theme addressed, in a general context, produced a result that relates to job satisfaction focused on the context of organizational intervention and productivity improvement.

\subsection{Main topics of the SWOT analysis}

Based on the concept proposed by Helms and Nixon (2010), a SWOT analysis was carried out on the final portfolio of articles, identifying the opportunities and threats, as well as the strengths and weaknesses of the proposed theme. Figure 5 presents a SWOT matrix listing the results found in the evaluation of the articles.

Figure 5 - SWOT analysis results

\begin{tabular}{|c|c|c|}
\hline & Helpful to achieving the objective & Harmful to achieving the objective \\
\hline 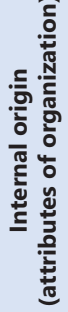 & $\begin{array}{l}\text { STRENGTHS } \\
\text { - The theme presents a recent approach; } \\
\text { - Various sampling methods; } \\
\text { - Implementation of strategies to improve } \\
\text { the well-being of university professors; } \\
\text { - Research in undergraduate and graduate } \\
\text { programs with different areas. }\end{array}$ & $\begin{array}{l}\text { WEAKNESSES } \\
\text { - Various interpretations of the work-life } \\
\text { balance concept; } \\
\text { - Concept divergence of work-life balance } \\
\text { between authors; } \\
\text { - There is no emphasis on research in } \\
\text { developing countries. }\end{array}$ \\
\hline 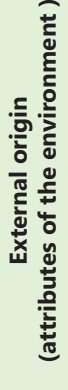 & $\begin{array}{l}\text { OPPORTUNITIES } \\
\text { - Increase the field of research in engineering, } \\
\text { information technology and social sciences; } \\
\text { - Meeting the needs of teachers generates } \\
\text { engagement between the work groups in } \\
\text { the educational institution; } \\
\text { - Attention to the well-being and job } \\
\text { satisfaction of teachers provides changes } \\
\text { in the quality of education; } \\
\text { - Research related to stress level as focus } \\
\text { of the problem. }\end{array}$ & $\begin{array}{l}\text { THREATS } \\
\text { - Gender inequality; } \\
\text { - The level of stress and responsibility varies } \\
\text { with each university; } \\
\text { - The harmony between the programs } \\
\text { would not necessarily make the teachers } \\
\text { develop the work-life balance. } \\
\text { - The articles do not address economics } \\
\text { as an impact on work-life balance of } \\
\text { higher education teachers. }\end{array}$ \\
\hline
\end{tabular}

Source: Own Authorship (2020) 
Strengths identified were the studies that presented attempts to apply their objectives in practice, proposing strategies to improve work-life balance, such as formulating policies for teachers to improve the organizational climate and reduce gender inequality in undergraduate and graduate programs (CHUNG et al., 2010; DELELLO; MCWHORTER; MARMION, 2018; SALTMARSH; RANDELL-MOON, 2015;), organization of seminars on health, well-being and time management (MAKHBUL; SHEIKH; SHEIKH, 2014), in addition to training for coordination with the function of obtaining a structured model to assist institutions to provide feedback in terms of relationship management (EBERMAN; SINGE; EASON, 2019; TOURANGEAU et al., 2015).

The different study methods were another strength identified, in which $60.3 \%$ of the articles evaluated used questionnaires, $28.2 \%$ interviews, $7.7 \%$ literature review and, finally, $3.8 \%$ interview and document analysis. In addition, the faculty is researched including several programs in the areas of physical Education (EASON et al., 2018; MAZEROLLE; EASON, 2016), engineering (NAYAK; SHARMA, 2018; PARAMASIVAM, 2015), mathematics (CABAY et al., 2018), nursing (TOURANGEAU et al., 2015), medicine (KRUEGER et al., 2017), pharmacy (LINDFELT et al., 2018), administration (DHANYA; KINSLIN, 2017; SMELTZER et al., 2016), among others, at the undergraduate and graduate levels. However, only $14.1 \%$ of the studies made comparisons between programs in different areas.

A weakness identified in the literature was the definition of the "work-life balance", which can generate doubt in the interpretation. The work-life balance is conceptualized in different ways in research and related to other concepts, such as health, psychology, management, engagement in the workplace, creating difficulties to differentiate certain concepts objectively. The concept of work-life balance found widely in research in different areas indicates the complexity of well-being in the professional environment of Higher Education institutions.

In general, some divergences are found in the concepts. Kinman and Jones (2008) portray that work-life balance is a way of balancing roles, in which fulfilling the responsibilities of one domain (work) does not harm the other domain (family). Kang, Park and Park (2019) state that the work-life balance addresses not only the structure of conflicts and family, but involves other concerns such as health, leisure activities, personal development and community commitments. Little research in developing countries was another weakness; the theme was highlighted by the United States of America and India. 
As an identified opportunity, a way to expand the study on the work-life balance of Higher Education teachers would be to enlarge the research fields to include more studies in the areas of engineering and information technology, which appear with a smaller number of publications in the reviewed articles. These areas present theories that can assist in the interpretation of complex situations, skills and the development of strategies to avoid conflicts in the professional and personal lives of teachers.

The biggest focus of the HEI is on the development of the teachers' career, quantifying participation in congresses and seminars or publications (EASON et al., 2018; HADLER, 2010). Another opportunity would be to value not only career growth, but also well-being and job satisfaction of teachers, as it can provide changes in the quality of Education. Research shows that if teachers have conflicts between family and professional life during the course of building their careers, and may not even continue to work in the area, everyone involved ends up having losses (CABAY et al., 2018; SETHI et al., 2017). Therefore, in relation to this divergence are financial expenses, in which there is no investment in psychological resources for teachers due to the expense of dedication in the various responsibilities (ZEHRA; RUKHSANA, 2020).

For teachers who present a high level of stress, strategies formulated by Higher Education institutions with a focus on psychological and social support were seen as effective for improvements in work-life balance (DEVI; LALU, 2018). The opportunity lies in advancing studies on the subject addressed, evaluating how these strategies can be used by Teaching professionals, eventually aiming at achieving the development of the work-life balance.

Finally, the issue of gender can be an opportunity found. Evaluated studies presented the female gender as a research audience (KANG; PARK; PARK, 2019; SUMATHI; VELMURUGAN, 2018). Countries such as the United States of America have a uniform gender distribution of Higher Education teachers, since $49.6 \%$ are women. Germany and Japan, on the other hand, show a gender disparity with a percentage of female teachers working in HEIs of $39.3 \%$ and $28.4 \%$ respectively (OECD, 2017). These data demonstrate that there are disparities between countries; however, women and men may have different reactions to job satisfaction, professional and family responsibilities, stress and conflicts, and therefore, equality of representativeness for both genders is fundamental.

Women showed a lower balance between professional and family life when compared to men (DENSON; SZELÉNYI; BRESONIS, 2018; MCCUTCHEON; 
MORRISON, 2018). In addition, some women sought alternative paths and different careers (CABAY et al., 2018). Another identified threat was the reasons such as workload and excessive activities, which generate stress or cause Teaching professionals in Higher Education institutions to choose to change careers (HADLER, 2010; SUMATHI; VELMURUGAN 2018).

There is an urgent need to review the failures in the public administrative policies of universities in relation to working time and family. These policies can be provided by universities (public and private) to offer teachers options to manage the work obligations and family needs. Among these policies, the following stand out: i) programs for the management of teachers' working time, including leisure habits and family support in personal planning (SALTMARSH; RANDELLMOON, 2015); ii) smaller classes; iii) faculty meetings using flexible methods, for example, virtual meetings (DELELLO; MCWHORTER; MARMION, 2018); and iv) informal work environment (EBERMAN; SINGE; EASON, 2019).

\section{Final considerations}

This article presented a systematic review of literature on work-life balance and the impact on the well-being of teachers who work in Higher Education institutions. Based on a systematic review of 53 articles retrieved from ScienceDirect, Scopus and Web of Science for the period of 2005 - May 2020, this article presented a rigorous systematic review methodology. From the final portfolio of the articles, some conclusions were drawn.

The main impacts on teachers' well-being due to the work-life balance, during the course of their careers in Higher Education institutions were: gender inequality, the level of stress at work and tension, career progress, classroom workload, publication of scientific articles, participation in congresses, compliance with deadlines and performance constants by the programs. The results of the SWOT analysis showed among the strengths the proposal of strategies to improve the work-life balance, such as, for example, formulating policies for teachers, like improving the organizational climate, reducing gender inequality in undergraduate and graduate programs, organizing seminars on health, well-being and time management, and training coordination to formulate a structured model of feedback in terms of relationship management. The various concepts of work-life balance identified in the literature were a weakness, with conceptual divergence between the authors. In addition, the lack of research on the proposed theme in developing countries was another weakness identified. In the opportunity, the increase of the research field in the area of engineering, since this area represented only $9.4 \%$ of the analyzed studies. As an identified threat, gender inequality was a topic 
that appeared as the focus of research in $24.5 \%$ of the studies, demonstrating the scenario of a traditional society with a mentality that disapproves of the increase in women's independence.

Higher Education institutions need to develop a more focused approach to the well-being of teachers, which would increase the chances of teachers maintaining their work-life balance during the development of their academic activities and, in the long run, maintaining quality Teaching. This review showed that Higher Education teachers present certain conflicts to balance family and professional commitments. As future research, it is recommended to study the work-life balance and the performance of teachers in universities, evaluating those who exercise the profession as a priority and those who also work in other professions such as health or business. 


\section{Equilíbrio entre trabalho e vida no Ensino Superior: uma revisão sistemática do impacto no bem-estar dos professores}

\section{Resumo}

O equilibrio entre trabalho e vida precisa ser exercido por individuos que desempenham funções no trabalho e na família, incluindo professores do Ensino Superior. O objetivo desse artigo é analisar o equilibrio entre trabalho e vida no Ensino Superior e o impacto no bem-estar dos professores. Com base em uma revisão sistemática de 53 artigos das bases ScienceDirect, Scopus e Web of Science de 2005 a 2020, esse artigo possui uma rigorosa metodologia de revisão sistemática usando as ferramentas de software Mendeley e EndNote. As ferramentas de software VOSviewer e Microsoft Excel também foram utilizadas nas seguintes técnicas: análise de citações e co-ocorrência de termos/palavras. Além disso, foram identificados na literatura os principais tópicos discutidos sobre o work-life balance entre professores do Ensino Superior, áreas de pesquisa, campo de atividade e análise SWOT (oportunidades, ameaças, pontos fortes e fracos). Os resultados sugerem que a desigualdade de gênero, o nível de estresse no trabalho e a ausência de um ambiente de trabalho saudável afetam o work-life balance e consequentemente o bem-estar dos professores do Ensino Superior.

Palavras-chave: Work-life balance. Professor. Universidade. Ensino Superior.

\section{Equilibrio entre trabajo y vida en la Educación Superior: una revisión sistemática del impacto en el bienestar de los docentes}

\section{Resumen}

El equilibrio entre trabajo y vida debe ser ejercido por personas que desempeñan funciones en el trabajo y en la familia, incluidos los maestros de Educación Superior. El propósito de este artículo es analizar el equilibrio entre trabajo y vida en la Educación Superior y el impacto en el bienestar de los docentes. Basado en una revisión sistemática de 53 artículos de las bases de datos ScienceDirect, Scopus y Web of Science de 2005 a 2020, este articulo tiene una metodología rigurosa de revisión sistemática utilizando las herramientas de software Mendeley y EndNote. Las herramientas de software VOSviewer y Microsoft Excel también se usaron en las siguientes técnicas: análisis de citas y co-ocurrencia de términos/ palabras. Además, se identificaron en la literatura los principales temas discutidos sobre el equilibrio trabajo-vida entre los docentes de Educación Superior, áreas de investigación, campo de actividad y análisis SWOT (oportunidades, amenazas, fortalezas y debilidades). Los resultados sugieren que la desigualdad de género, el nivel de estrés en el trabajo y la ausencia de un entorno laboral saludable afectan el equilibrio entre el trabajo y la vida y, en consecuencia, el bienestar de los docentes de Educación Superior.

Palabras clave: Equilibrio trabajo-vida. Profesor. Universidad. Enseñanza Superior. 


\section{References}

ABRAMOV, R.; GRUZDEV, I.; TERENTEV, E. Working time and role strains of research and teaching staff in a modern Russian University. Voprosy Obrazovaniya-Educational Studies, Moscow, v. 17,n. 1, p.88-111, 2017. https://doi.org/10.17323/1814-9545-2017-1-88-111

AMITH, D.; VINAY, K. B.; GOWRAMMA, Y. P. Effective strategies for stress management in work life balance among women teaching profession (with special reference to technical teachers). International Journal of Recent Technology and Engineering, Bophal, v. 8, n. 1S, p. 177-182, May 2019.

ARCHAMBAULT, E. et al. Comparing bibliometric statistics obtained from the web of science and scopus. Journal of the American Society for Information Science and Technology, Syracuse, v. 60, n. 7, p. 1320-1326, Apr. 2009. https://doi: 10.1002/asi.21062

BAKER, M. Choices or constraints? Family responsibilities, gender and academic career. Journal of Comparative Family Studies, [s. 1.], v. 41, n. 1, p. 1-18, Dec. 2010. https://doi:10.2307/41604335

BEDDOES, K.; PAWLEY, A. L. Different people have different priorities: work-family balance, gender, and the discourse of choice. Studies in Higher Education, London, v. 39, n. 9, p. 1573-1585, 2014. https://doi.org/10.1080/03075079.2013.801432

BEER, L. E. et al. Awareness, integration and Interconnectedness: contemplative practices of higher education professionals. Journal of Transformative Education, [s. 1.], v. 13, n. 2, p. 161-185, Mar. 2015. https://doi.org/10.1177/1541344615572850

BEIGI, M.; SHIRMOHAMMADI, M.; KIM, S. Living the academic life: a model for work-family conflict. Work, [s. 1.], v. 53, n. 3, p. 459-468, 2016. https://doi.org/10.3233/WOR-152173

BERHEIDE, C. W. et al. Gender, type of higher education institution, and faculty work-life integration in the United States. Community, Work and Family, [s. 1.], v. 23, n. 2, p. 118-132, Jun 2020. https://doi.org/10.1080/13668803.2020.1776220

BESSELAAR, P.; HEIMERIKS, G. Mapping research topics using word-reference co-occurrences: a method and an exploratory case study. Scientometrics, Budapeste, v. 68, n. 1, p. 377-303, 2006. https://doi.org/10.1007/s11192-006-0118-9 
CABAY, M. et al. Chilly climates, balancing acts, and shifting pathways: What happens towomen in STEM doctoral programs. Social Sciences, [s. 1.], v. 7, n. 2, p. 1-23, 2018. https://doi.org/10.3390/socsci7020023

CATANO, V. et al. Occupational stress in Canadian universities: a national survey. International Journal of Stress Management, [s. 1.], v. 17, n. 3, p. 232-258, 2010. https://doi.org/10.1037/a0018582

CHUNG, K. C. et al. Predictors of job satisfaction among academic faculty members: do instructional and clinical staff differ? Medical Education, Oxford, v. 44, n. 10, p. 985-995, Oct. 2010. https://doi.org/10.1111/j.1365-2923.2010.03766.x

DELELLO, J. A.; MCWHORTER, R. R.; MARMION, S. L. Understanding the productivity of faculty members in higher education. International Journal of Management in Education, [s. 1.], v. 12, n. 2, p. 154-178, Jan. 2018. https://doi.org/10.1504/IJMIE.2018.090738

DENSON, N.; SZELÉNYI, K.; BRESONIS, K. Correlates of work-life balance for faculty across racial/ethnic groups. Research in Higher Education, New York, v. 59, n. 2, p. 226-247, Mar. 2018. https://doi.org/10.1007/s11162-017-9464-0

DEVI, M. P.; LALU, A. N. G. F. Stress and work-life balance of school teachers: a social work intervention. Journal of Social Work Education and Practice, [s. 1.], v. 3, n. 2, p. 57-61, 2018.

DHANYA, J. S.; KINSLIN, D. Clair model for better work life balance and empowerment of women faculty in professional colleges of Kerala. International Journal of Applied Business and Economic Research, [s. 1.], v. 15, n. 5, p. 207-246, 2017.

DUBAS-JAKOBCZYK, K. et al. Exploring satisfaction and migration intentions of physicians in three university hospitals in Poland. International Journal of Environmental Research and Public Health, Basel, v. 17, n. 1, p. 43-56, Jan. 2020. https://doi.org/10.3390/ijerph17010043

DZIKOWSKI, P. A bibliometric analysis of born global firms. Journal of Business Research, New York, v. 85, n. 1, p. 281-294, Apr. 2018. https://doi.org/10.1016/j.jbusres.2017.12.054

EASON, C. M. et al. Multilevel examination of job satisfaction and career intentions of collegiate athletic trainers: a quantitative approach. Journal of Athletic Training, Dallas, v. 53, n. 1, p. 80-87, Jan. 2018. https://doi.org/10.4085/1062-6050-52.11.27 
EBERMAN, L.; SINGE, S. M.; EASON, C. M. Formal and informal work-life balance practices of athletic trainers in collegiate and university settings. Journal of Athletic Training, Dallas, v. 54, n. 5, p. 556-561, May 2019. https://doi.org/10.4085/1062-6050-245-17

FAZAL, S. et al. Barriers and enablers of women's academic careers in Pakistan. Asian Journal of Womens Studies, [s. 1.], v. 25, n. 2, p. 217-238, Jun 2019. https://doi.org/10.1080/12259276.2019.1607467

GOODING, L. F. Work-life factors and job satisfaction among music therapy educators: a national survey. Music Therapy Perspectives, [s. 1.], v. 36, n. 1, p. 97-107, 2018. https://doi.org/10.1093/mtp/mix015

GRAWITCH, M. J.; TRARES, S.; KOHLER, J. M. Healthy workplace practices and employee outcomes. International Journal of Stress Management, [s. 1.], v. 14, n. 3, p. 275-293, Aug. 2007. https://doi.org/10.1037/1072-5245.14.3.275

HADLER, C. Workplace health management in practical experience: "Impuls Test" as an instrument for analysis on the path to a healthy university. Pravention und Gesundheitsforderung, [s. 1.], v. 5, n. 3, p. 203-214, Aug. 2010. https://doi.org/10.1007/s11553-010-0253-2

HELMS, M. M.; NIXON, J. Exploring SWOT analysis - where are we now? A review of academic research from the last decade. Journal of Strategy and Management, Cambridge, v. 3, n. 3, p. 215-251, Aug. 2010. https://doi.org/10.1108/17554251011064837

HOUSTON, D.; MEYER, L. H.; PAEWAI, S. Academic staff workloads and job satisfaction: Expectations and values in academe. Journal of Higher Education Policy and Management, Abingdon, v. 28, n. 1, p. 17-30, Aug. 2006. https://doi.org/10.1080/13600800500283734

JAIN, A.; MISHRA, S.; YADAV, G. Physical, emotional and spiritual health of faculty: an exploratory study. International Journal of Work Organisation and Emotion, [s. 1.], v. 9, n. 4, p. 348-361, 2018. https://doi.org/10.1504/IJWOE.2018.097176

JOHNSON, S. J.; WILLIS, S. M.; EVANS, J. An examination of stressors, strain, and resilience in academic and non-academic U.K. university job roles. International Journal of Stress Management, Washington, v. 26, n. 2, p. 162-172, May 2019. https://doi.org/10.1037/str0000096 
KANG, M.; PARK, H. J.; PARK, J. Teachers as good mothers, mothers as good teachers: Functional and ideological work-family alignment in the South Korean teaching profession. Gender, Work and Organization, [s. 1.], v. 26, n. 6, p. 1-37, 2019. https://doi.org/10.1111/gwao.12396

KINMAN, G.; JONES, F. Effort-reward imbalance, over-commitment and work-life conflict: testing an expanded model. Journal of Managerial Psychology, Bradford, v. 23, n. 3, p. 236-251, 2008. https://doi.org/10.1108/02683940810861365

KRUEGER, P. et al. Predictors of job satisfaction among academic family medicine faculty: findings from a faculty work-life and leadership survey. Canadian Family Physician, [s. 1.], v. 63, n. 3, p. e177-185, Mar. 2017.

LEARNED, E. et al. Business policy, text and cases. Homewood: Richard D. Irwin, 1965

LESTER, J. Cultures of work-life balance in higher education: a case of fragmentation. Journal of Diversity in Higher Education, Washington, v. 8, n. 3, p. 139-156, 2015. https://doi.org/10.1037/a0039377

LINDFELT, T. et al. The impact of work-life balance on intention to stay in academia: Results from a national survey of pharmacy faculty. Research in Social and Administrative Pharmacy, New York, v.14, n.4, p.387-390, 2018. https://doi.org/10.1016/j.sapharm.2017.04.008

LINDFELT, T. A.; IP, E. J.; BARNETT, M. J. Survey of career satisfaction, lifestyle, and stress levels among pharmacy school faculty. American Journal of Health-System Pharmacy, Bethesda, v. 72, n. 18, p. 1573-1578, Sep. 2015. https://doi.org/10.2146/ajhp140654

MCCUTCHEON, J. M.; MORRISON, M. A. It's "like walking on broken glass": Pan-Canadian reflections on work-family conflict from psychology women faculty and graduate students. Feminism and Psychology, [s. 1.], v. 28, n. 2, p. 231-252, May 2018. https://doi.org/10.1177/0959353517739641

MAKHBUL, Z. M.; SHEIKH, M. H.; SHEIKH, K. Measuring the effect of commitment on occupational stressors and individual productivity ties. Journal Pengurusan, Selangor, v. 40, p. 103-113, 2014.

MARAGATHAM, B.; AMUDHA, R.; MOTHA, L. C. S. Work life balance of married women teachers in higher education in kumbakonam town. International Journal of Economic Research, [s. 1.], v. 14, n. 5, p. 329-337, Jan. 2017. 
MAZEROLLE, S.; EASON, C. A longitudinal examination of work-life balance in the collegiate setting. Journal of Athletic Training, Dallas, v. 51, n. 3, p. 223-232, Mar. 2016. https://doi.org/10.4085/1062-6050-51.4.03

NAYAK, P.; SHARMA, N. Managing faculty's work-life balance in Indian business schools. Teorija in Praksa, Ljubljana, v. 55, n. 3, p. 604-621, Jan. 2018.

NAZ, S.; FAZAL, S.; KHAN, M. I. Perceptions of women academics regarding work-life balance: a Pakistan case. Management in Education, London, v. 31, n. 2, p. 88-93, Apr. 2017. https://doi.org/10.1177/0892020617696633

NILSSON, M.; BLOMQVIST, K.; ANDERSSON, I. Salutogenic resources in relation to teachers' work-life balance. Work, Amsterdam, v. 56, n. 4, p. 591-602, 2017. https://doi.org/10.3233/WOR-172528

NORRIS, M.; OPPENHEIM, C. Comparing alternatives to the Web of Science for coverage of the social sciences' literature. Journal of Informetrics, [s. 1.], v. 1, n. 2, p. 161-169, Apr. 2007. https://doi.org/10.1016/j.joi.2006.12.001

\section{ORGANISATION FOR ECONOMIC CO-OPERATION AND}

DEVELOPMENT - OECD. Distribution of teachers by age and gender. Paris, 2017. Available from: https://stats.oecd.org/Index.aspx?DataSetCode=EAG_ PERS_SHARE_AGE. Access in: 5 jun. 2020.

PARAMASIVAM, G. M. Role of self-efficacy and family supportive organizational perceptions in teachers' organizational citizenship behaviour: a study on engineering college teachers in India. Asian Education and Development Studies, Bingley, v. 4, n. 4, p. 394-408, Oct. 2015. https://doi.org/10.1108/AEDS-01-2015-0001

PIGNATA, S. et al. A qualitative study of hr/ohs stress interventions in australian universities. International Journal of Environmental Research and Public Health, Basel, v. 15, n. 1, e103, Jan. 2018. https://doi.org/10.3390/ijerph15010103

PU, J. et al. The effect of psychological capital between work-family conflict and job burnout in Chinese university teachers: testing for mediation and moderation. Journal of Health Psychology, Los Angeles, v. 22, n. 14, p. 1799-1807, Dec. 2017. https://doi.org/10.1177/1359105316636950 
ROTENBERG, L.; CARLOS, R. S. L. How social acceleration affects the work practices of academics: a study in Brazil. German Journal of Human Resource Management, [s. 1.], v. 32, n. 3, p. 257-270, Aug. 2018. https://doi.org/10.1177/2397002218788781

SALTMARSH, S.; RANDELL-MOON, H. Managing the risky humanity of academic workers: risk and reciprocity in university work-life balance policies. Policy Futures in Education, [s. 1.], v. 13, n. 5, p. 662-682, June 2015. https://doi.org/10.1177/1478210315579552

SEDIGHI, M. Application of word co-occurrence analysis method in mapping of the scientific fields (case study: the field of Informetrics). Library Review, Bingley, v. 65, n. 1/2, p. 52-64, 2016. https://doi.org/10.1108/LR-07-2015-0075.

SETHI, A. et al. Exploring the tensions of being and becoming a medical educator. BMC Medical Education, London, v. 17, n. 1, p. 112-129, Mar. 2017. https://doi.org/10.1186/s12909-017-0894-3

SMELTZER, S. C. et al. Psychometric analysis of the work/life balance self-assessment scale. Journal of Nursing Measurement, New York, v. 24, n. 1, p. 5-14, 2016. https://doi.org/10.1891/1061-3749.24.1.5

SONI, P.; BAKHRU, K. M. Understanding triangulated collaboration of work-life balance, personality traits and eudaimonic well-being. Problems and Perspectives in Management, Cham, v. 17, n. 2, p. 63-82, 2019. https://doi.org/10.21511/ppm.17(2).2019.05

SOOMRO, A. A.; BREITENECKER, R. J.; SHAH, S. A. M. Relation of work-life balance, work-family conflict, and family-work conflict with the employee performance-moderating role of job satisfaction. South Asian Journal of Business Studies, [s. 1.], v. 7, n. 1, p. 129-146, Mar. 2018. https://doi.org/10.1108/SAJBS-02-2017-0018

SULLIVAN, T. A. Greedy institutions, overwork, and work-life balance. Sociological Inquiry, Austin, v. 84, n. 1, p. 1-15, Feb. 2014. https://doi.org/10.1111/soin.12029

SUMATHI, V.; VELMURUGAN, R. Job satisfaction of female faculty in Arts and Science Colleges in Coimbatore District. International Journal of Engineering and Technology, Gurpukur, v. 7, n. 3, p. 129-133, 2018. 
TOURANGEAU, A. E. et al. Generation-specific incentives and disincentives for nurse faculty to remain employed. Journal of Advanced Nursing, Oxford, v. 71, n. 5, p. 1019-1031, May 2015. https://doi.org/10.1111/jan.12582

TYTHERLEIGH, M. Y. et al. Occupational stress in UK higher education institutions: a comparative study of all staff categories. Higher Education Research and Development, [s. 1.], v. 24, n. 1, p. 41-61, 2005. https://doi.org/10.1111/j.1464-0597.2006.00254.x

TYTHERLEIGH, M. Y. et al. Gender, health and stress in English university staff - Exposure or vulnerability? Applied Psychology, [s. 1.], v. 56, n. 2, p. 267-287, Apr. 2007. https://doi.org/10.1080/0729436052000318569

VAN ECK, N.; WALTMAN, L. Software survey: VOSviewer, a computer program for bibliometric mapping. Scientometrics, Budapeste, v. 84, n. 2 , p. 523-538, Dec. 2009.

YOU, D. Work-life balance: can you actually make that happen?

Frontiers in Pediatrics, Lausanne, v. 3, n. 1, p. 1-15, 2016.

https://doi.org/10.3389/fped.2015.00117

ZEHRA, F.; RUKHSANA, N. Faculty job satisfaction in a private medical university: a cross-sectional study from Karachi, Pakistan. Rawal Medical Journal, [s. 1.], v. 45, n. 1, p. 211-217, 2020. 
Appendix A - Characteristics of the assessed studies

\begin{tabular}{|c|c|c|c|c|c|}
\hline ID & $\begin{array}{c}\text { Main topics } \\
\text { discussed about } \\
\text { work-life balance }\end{array}$ & Study areas & $\begin{array}{l}\text { Practice field } \\
\text { (Teaching, } \\
\text { research and } \\
\text { management) }\end{array}$ & Citation & Reference \\
\hline 1 & $\begin{array}{c}\text { Workload } \\
\text { management }\end{array}$ & $\begin{array}{l}\text { Education and } \\
\text { Administration }\end{array}$ & $\begin{array}{l}\text { Teaching and } \\
\text { Research }\end{array}$ & 441 & $\begin{array}{c}\text { Houston, Meyer } \\
\text { and Paewai } \\
(2006)\end{array}$ \\
\hline 2 & $\begin{array}{l}\text { Workplace stress; } \\
\text { Work overload }\end{array}$ & Education & Teaching & 427 & $\begin{array}{c}\text { Tytherleigh et al. } \\
\text { (2005) }\end{array}$ \\
\hline 3 & $\begin{array}{c}\text { Healthy workplace; } \\
\text { Employee } \\
\text { involvement }\end{array}$ & $\begin{array}{c}\text { Medicine, } \\
\text { Psychology and } \\
\text { Administration }\end{array}$ & Teaching & 244 & $\begin{array}{l}\text { Grawitch, Trares } \\
\text { and Kohler (2007) }\end{array}$ \\
\hline 4 & $\begin{array}{c}\text { Role conflict, } \\
\text { Workplace stress }\end{array}$ & $\begin{array}{l}\text { Psychology and } \\
\text { Administration }\end{array}$ & $\begin{array}{c}\text { Teaching, } \\
\text { Research and } \\
\text { Management }\end{array}$ & 168 & $\begin{array}{l}\text { Kinman and } \\
\text { Jones (2008) }\end{array}$ \\
\hline 5 & $\begin{array}{l}\text { Workplace stress; } \\
\text { Occupational health }\end{array}$ & $\begin{array}{c}\text { Medicine, } \\
\text { Psychology and } \\
\text { Administration }\end{array}$ & $\begin{array}{l}\text { Teaching and } \\
\text { Research }\end{array}$ & 133 & $\begin{array}{l}\text { Catano et al. } \\
\qquad(2010)\end{array}$ \\
\hline 6 & Gender inequality & Psychology & Teaching & 111 & $\begin{array}{c}\text { Tytherleigh et al. } \\
\text { (2007) }\end{array}$ \\
\hline 7 & $\begin{array}{l}\text { Job satisfaction; } \\
\text { Healthcare Educators }\end{array}$ & $\begin{array}{l}\text { Medicine and } \\
\text { Education }\end{array}$ & $\begin{array}{l}\text { Teaching, } \\
\text { Research and } \\
\text { Management }\end{array}$ & 84 & $\begin{array}{l}\text { Chung et al. } \\
\text { (2010) }\end{array}$ \\
\hline 8 & $\begin{array}{l}\text { Gender inequality; } \\
\text { Workplace stress }\end{array}$ & $\begin{array}{l}\text { Sociology and } \\
\text { Social Work }\end{array}$ & $\begin{array}{l}\text { Teaching and } \\
\text { Research }\end{array}$ & 78 & Baker (2010) \\
\hline 9 & Gender inequality & Education & Teaching & 71 & $\begin{array}{l}\text { Beddoes and } \\
\text { Pawley (2014) }\end{array}$ \\
\hline 10 & Workplace policies & Sociology & $\begin{array}{l}\text { Teaching and } \\
\text { Management }\end{array}$ & 52 & Sullivan (2014) \\
\hline 11 & $\begin{array}{l}\text { Healthy workplace; } \\
\text { Personnel turnover }\end{array}$ & Nursing & Teaching & 51 & $\begin{array}{l}\text { Tourangeau et al. } \\
\text { (2015) }\end{array}$ \\
\hline 12 & $\begin{array}{l}\text { Gender inequality; } \\
\text { Organization culture }\end{array}$ & $\begin{array}{l}\text { Education and } \\
\text { Psychology }\end{array}$ & $\begin{array}{l}\text { Teaching and } \\
\text { Management }\end{array}$ & 37 & Lester (2015) \\
\hline 13 & $\begin{array}{l}\text { Healthcare Educators; } \\
\text { Career choice }\end{array}$ & $\begin{array}{l}\text { Medicine and } \\
\text { Education }\end{array}$ & $\begin{array}{l}\text { Teaching and } \\
\text { Research }\end{array}$ & 37 & Sethi et al. (2017) \\
\hline 14 & Healthy workplace & Psychology & Teaching & 36 & Pu et al. (2017) \\
\hline 15 & $\begin{array}{l}\text { Contemplative } \\
\text { practices }\end{array}$ & Education & Teaching & 32 & Beer et al. (2015) \\
\hline 16 & $\begin{array}{l}\text { Career progression; } \\
\text { Job satisfaction; } \\
\text { Workplace stress }\end{array}$ & Medicine & Teaching & 23 & $\begin{array}{l}\text { Lindfelt, Ip and } \\
\text { Barnett (2015) }\end{array}$ \\
\hline 17 & $\begin{array}{l}\text { Employee } \\
\text { performance; Work- } \\
\text { life conflict }\end{array}$ & Administration & Teaching & 21 & $\begin{array}{c}\text { Soomro, } \\
\text { Breitenecker and } \\
\text { Shah (2018) }\end{array}$ \\
\hline
\end{tabular}




\begin{tabular}{|c|c|c|c|c|c|}
\hline ID & $\begin{array}{c}\text { Main topics } \\
\text { discussed about } \\
\text { work-life balance }\end{array}$ & Study areas & $\begin{array}{l}\text { Practice field } \\
\text { (Teaching, } \\
\text { research and } \\
\text { management) }\end{array}$ & Citation & Reference \\
\hline 18 & $\begin{array}{c}\text { Career progression; } \\
\text { Workload } \\
\text { management }\end{array}$ & $\begin{array}{l}\text { Psychology, } \\
\text { Education and } \\
\text { Medicine }\end{array}$ & Teaching & 20 & $\begin{array}{c}\text { Mazerolle and } \\
\text { Eason (2016) }\end{array}$ \\
\hline 19 & $\begin{array}{l}\text { Job satisfaction; } \\
\text { Healthy workplace }\end{array}$ & $\begin{array}{l}\text { Nursing, } \\
\text { Medicine and } \\
\text { Education }\end{array}$ & Teaching & 19 & $\begin{array}{c}\text { Krueger et al. } \\
\text { (2017) }\end{array}$ \\
\hline 20 & $\begin{array}{l}\text { Work environment; } \\
\text { Healthy workplace }\end{array}$ & Multidisciplinary & $\begin{array}{l}\text { Teaching and } \\
\text { Management }\end{array}$ & 18 & $\begin{array}{c}\text { Nilsson, } \\
\text { Blomqvist and } \\
\text { Andersson (2017) }\end{array}$ \\
\hline 21 & $\begin{array}{l}\text { Job satisfaction; } \\
\text { Work-life conflict }\end{array}$ & Multidisciplinary & Teaching & 16 & $\begin{array}{c}\text { Beigi, } \\
\text { Shirmohammadi } \\
\text { and Kim (2016) }\end{array}$ \\
\hline 22 & $\begin{array}{c}\text { Workplace } \\
\text { stress; Workload } \\
\text { management }\end{array}$ & $\begin{array}{l}\text { Administration } \\
\text { and Economics }\end{array}$ & $\begin{array}{l}\text { Research and } \\
\text { Management }\end{array}$ & 15 & $\begin{array}{c}\text { Makhbul, Sheikh } \\
\text { and Sheikh } \\
\text { (2014) }\end{array}$ \\
\hline 24 & Gender inequality & Multidisciplinary & $\begin{array}{l}\text { Teaching and } \\
\text { Research }\end{array}$ & 13 & $\begin{array}{c}\text { Cabay et al. } \\
\text { (2018) }\end{array}$ \\
\hline 23 & Race inequality & Education & $\begin{array}{l}\text { Teaching and } \\
\text { Research }\end{array}$ & 13 & $\begin{array}{c}\text { Denson, Szelényi } \\
\text { and Bresonis } \\
(2018)\end{array}$ \\
\hline 25 & $\begin{array}{l}\text { Workplace policies; } \\
\text { Risk and reciprocity }\end{array}$ & $\begin{array}{l}\text { Education and } \\
\text { Administration }\end{array}$ & Teaching & 13 & $\begin{array}{l}\text { Saltmarsh and } \\
\text { Randell-Moon } \\
\text { (2015) }\end{array}$ \\
\hline 26 & Workplace stress & $\begin{array}{c}\text { Medicine, } \\
\text { Psychology and } \\
\text { Administration }\end{array}$ & Teaching & 12 & $\begin{array}{l}\text { Johnson, Willis } \\
\text { and Evans (2019) }\end{array}$ \\
\hline 27 & $\begin{array}{l}\text { Workplace stress; } \\
\text { Personnel turnover; } \\
\text { Career progression }\end{array}$ & $\begin{array}{c}\text { Pharmacy, } \\
\text { Medicine and } \\
\text { Administration }\end{array}$ & $\begin{array}{l}\text { Teaching and } \\
\text { Management }\end{array}$ & 12 & $\begin{array}{l}\text { Lindfelt et al. } \\
\quad(2018)\end{array}$ \\
\hline 28 & Healthcare Educators & $\begin{array}{l}\text { Nursing and } \\
\text { Education }\end{array}$ & Teaching & 12 & $\begin{array}{c}\text { Smeltzer et al. } \\
(2016)\end{array}$ \\
\hline 30 & Healthy workplace & Medicine & Research & 10 & Hadler (2010) \\
\hline 29 & Gender inequality & Education & Teaching & 10 & $\begin{array}{l}\text { Naz, Fazal and } \\
\text { Khan (2017) }\end{array}$ \\
\hline 31 & $\begin{array}{l}\text { Workplace policies; } \\
\text { Career progression }\end{array}$ & $\begin{array}{c}\text { Education, } \\
\text { Sociology and } \\
\text { Political Science }\end{array}$ & $\begin{array}{l}\text { Teaching and } \\
\text { Research }\end{array}$ & 9 & $\begin{array}{l}\text { Paramasivam } \\
\text { (2015) }\end{array}$ \\
\hline
\end{tabular}


Continuation

\begin{tabular}{|c|c|c|c|c|c|}
\hline ID & $\begin{array}{c}\text { Main topics } \\
\text { discussed about } \\
\text { work-life balance }\end{array}$ & Study areas & $\begin{array}{l}\text { Practice field } \\
\text { (Teaching, } \\
\text { research and } \\
\text { management) }\end{array}$ & Citation & Reference \\
\hline 32 & $\begin{array}{c}\text { Workplace strategies; } \\
\text { Organizational } \\
\text { culture }\end{array}$ & $\begin{array}{l}\text { Psychology, } \\
\text { Education, } \\
\text { Physiotherapy } \\
\text { and Medicine }\end{array}$ & Teaching & 8 & $\begin{array}{l}\text { Eason et al. } \\
\quad(2018)\end{array}$ \\
\hline 34 & $\begin{array}{l}\text { Gender inequality; } \\
\text { Work-life conflict }\end{array}$ & $\begin{array}{l}\text { Psychology and } \\
\text { Sociology }\end{array}$ & $\begin{array}{l}\text { Teaching and } \\
\text { Research }\end{array}$ & 8 & $\begin{array}{c}\text { McCutcheon and } \\
\text { Morrison (2018) }\end{array}$ \\
\hline 33 & $\begin{array}{l}\text { Workplace stress; } \\
\text { Well-being; } \\
\text { Leadership }\end{array}$ & $\begin{array}{l}\text { Engineering and } \\
\text { Medicine }\end{array}$ & Management & 8 & $\begin{array}{l}\text { Pignata et al. } \\
\qquad(2018)\end{array}$ \\
\hline 35 & Gender inequality & $\begin{array}{l}\text { Administration } \\
\text { and Economics }\end{array}$ & Teaching & 5 & $\begin{array}{l}\text { Dhanya and } \\
\text { Kinslin (2017) }\end{array}$ \\
\hline 37 & $\begin{array}{l}\text { Workload } \\
\text { management; Job } \\
\text { satisfaction }\end{array}$ & Multidisciplinary & $\begin{array}{l}\text { Teaching, } \\
\text { Research and } \\
\text { Management }\end{array}$ & 4 & $\begin{array}{c}\text { Abramov, } \\
\text { Gruzdev and } \\
\text { Terentev (2017) }\end{array}$ \\
\hline 36 & $\begin{array}{l}\text { Faculty performance; } \\
\text { Faculty accountability }\end{array}$ & $\begin{array}{l}\text { Education and } \\
\text { Administration }\end{array}$ & $\begin{array}{l}\text { Teaching, } \\
\text { Research and } \\
\text { Management }\end{array}$ & 4 & $\begin{array}{c}\text { Delello, } \\
\text { McWhorter } \\
\text { and Marmion } \\
\text { (2018) }\end{array}$ \\
\hline 38 & Work life satisfaction & $\begin{array}{l}\text { Social and } \\
\text { Humanities }\end{array}$ & Teaching & 3 & Gooding (2018) \\
\hline 39 & $\begin{array}{c}\text { Workload } \\
\text { management }\end{array}$ & Administration & Management & 3 & $\begin{array}{l}\text { Rotenberg and } \\
\text { Carlos (2018) }\end{array}$ \\
\hline 41 & $\begin{array}{l}\text { Career progression; } \\
\text { Gender inequality }\end{array}$ & $\begin{array}{l}\text { Psychology and } \\
\text { Sociology }\end{array}$ & Teaching & 1 & Fazal et al. (2019) \\
\hline 43 & $\begin{array}{l}\text { Healthy workplace; } \\
\text { Physical activity; } \\
\text { Workplace stress }\end{array}$ & $\begin{array}{l}\text { Administration } \\
\text { and Psychology }\end{array}$ & $\begin{array}{l}\text { Teaching, } \\
\text { Research and } \\
\text { Management }\end{array}$ & 1 & $\begin{array}{l}\text { Jain, Mishra and } \\
\text { Yadav (2018) }\end{array}$ \\
\hline 40 & $\begin{array}{l}\text { Gender inequality; } \\
\text { Organizational } \\
\text { culture }\end{array}$ & $\begin{array}{l}\text { Psychology, } \\
\text { Sociology, } \\
\text { Administration } \\
\text { and Law }\end{array}$ & Teaching & 1 & $\begin{array}{l}\text { Kang, Park and } \\
\text { Park (2019) }\end{array}$ \\
\hline 42 & Well-being & Administration & $\begin{array}{l}\text { Teaching and } \\
\text { Management }\end{array}$ & 1 & $\begin{array}{c}\text { Soni and Bakhru } \\
\text { (2019) }\end{array}$ \\
\hline 44 & Healthy workplace & Medicine & Research & 1 & You (2016) \\
\hline 46 & $\begin{array}{l}\text { Multirole; } \\
\text { Workplace stress; } \\
\text { Gender inequality }\end{array}$ & $\begin{array}{c}\text { Engineering } \\
\text { and Information } \\
\text { Technology }\end{array}$ & Teaching & 0 & $\begin{array}{c}\text { Amith, Vinay } \\
\text { and Gowramma } \\
\text { (2019) }\end{array}$ \\
\hline 52 & Work-life conflict & Medicine & Management & 0 & $\begin{array}{l}\text { Berheide et al. } \\
\text { (2020) }\end{array}$ \\
\hline
\end{tabular}




\begin{tabular}{|c|c|c|c|c|c|}
\hline ID & $\begin{array}{c}\text { Main topics } \\
\text { discussed about } \\
\text { work-life balance }\end{array}$ & Study areas & $\begin{array}{l}\text { Practice field } \\
\text { (Teaching, } \\
\text { research and } \\
\text { management) }\end{array}$ & Citation & Reference \\
\hline 48 & $\begin{array}{c}\text { Well-being; } \\
\text { Workplace stress }\end{array}$ & $\begin{array}{l}\text { Education and } \\
\text { Social Work }\end{array}$ & Teaching & 0 & $\begin{array}{l}\text { Devi and Lalu } \\
\text { (2018) }\end{array}$ \\
\hline 50 & $\begin{array}{l}\text { Organizational } \\
\text { climate }\end{array}$ & $\begin{array}{l}\text { Pharmacy and } \\
\text { Engineering }\end{array}$ & $\begin{array}{l}\text { Teaching and } \\
\text { Management }\end{array}$ & 0 & $\begin{array}{l}\text { Dubas-Jakobczyk } \\
\text { et al. (2020) }\end{array}$ \\
\hline 45 & $\begin{array}{l}\text { Workplace policies; } \\
\text { Work-life conflict }\end{array}$ & $\begin{array}{l}\text { Psychology, } \\
\text { Education and } \\
\text { Medicine }\end{array}$ & Teaching & 0 & $\begin{array}{l}\text { Eberman, Singe } \\
\text { and Eason (2019) }\end{array}$ \\
\hline 51 & Gender inequality & Economics & Teaching & 0 & $\begin{array}{l}\text { Maragatham, } \\
\text { Amudha and } \\
\text { Motha (2017) }\end{array}$ \\
\hline 49 & Organization culture & $\begin{array}{l}\text { Engineering and } \\
\text { Economics }\end{array}$ & $\begin{array}{l}\text { Management } \\
\text { and Teaching }\end{array}$ & 0 & $\begin{array}{c}\text { Nayak and } \\
\text { Sharma (2018) }\end{array}$ \\
\hline 47 & $\begin{array}{l}\text { Gender inequality; } \\
\text { Job satisfaction }\end{array}$ & $\begin{array}{l}\text { Engineering and } \\
\text { Administration }\end{array}$ & $\begin{array}{l}\text { Teaching and } \\
\text { Management }\end{array}$ & 0 & $\begin{array}{c}\text { Sumathi and } \\
\text { Velmurugan } \\
\text { (2018) }\end{array}$ \\
\hline 53 & $\begin{array}{c}\text { Flexible career; } \\
\text { Workplace policies }\end{array}$ & Medicine & Teaching & 0 & $\begin{array}{c}\text { Zehra and } \\
\text { Rukhsana (2020) }\end{array}$ \\
\hline
\end{tabular}

Source: Own Authorship (2020) 


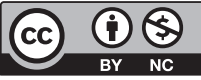

\section{Information about the authors}

Luciane Silva Franco: Masters student in the Postgraduate Program in Production Engineering, Universidade Tecnológica Federal do Paraná. Capes scholarship - Coordination for the Improvement of Higher Education Personnel. Contato: Lu05-franco@hotmail.com

iD http://orcid.org/0000-0003-1913-9275

Claudia Tania Picinin: PhD in Business Administration, Universidade Positivo. Universidade Tecnológica Federal do Paraná, Department of Production Engineering. Fundação Araucária scholarship. Contato: claudia.picinin@utfpr.edu.br

iD http://orcid.org/0000-0003-4844-3516

Luiz Alberto Pilatti: Master in Education, Universidade Metodista de Piracicaba. $\mathrm{PhD}$ in Physical Education, Universidade Estadual de Campinas. Universidade Tecnológica Federal do Paraná, Department of Production Engineering. Research Productivity Scholarship - CNPq. Contato: lapilatti@utfpr.edu.br

iD http://orcid.org/0000-0003-2679-9191

Antonio Carlos Franco: Masters student in the Postgraduate Program in Production Engineering, Universidade Tecnológica Federal do Paraná.

Contato: francoancf@hotmail.com

iD http://orcid.org/0000-0003-1616-2648 